\title{
Research on the development strategies of Wuhan local tourism based on sports events
}

\author{
Wu Zhong ${ }^{1, a,{ }^{*}}$ \\ ${ }^{1}$ Physical Education School, Wuhan Business University, Wuhan, China \\ a7849800@qq.com
}

Keywords: Sports events, Wuhan local tourism, Development strategy.

\begin{abstract}
In recent years, sports events promote the development of local tourism industry as a new platform. In this paper, it explores the Wuhan sports events and the present situation of the development of the tourism industry in Wuhan, analyzes Wuhan sports characteristic and impact on the local tourism development, and puts forward a sound management system to optimize the design of the event layout resource integration innovation related products on the moving platform based on the Wuhan sports tourism related theory as the foundation to promote Wuhan rapid economic growth and Wuhan tourism industry, and sports development to provide the reference.
\end{abstract}

\section{基于体育赛事的武汉地方旅游业发展对策研究}

\author{
吴钟 $1, a$ \\ 1武汉商学院体育学院, 武汉, 湖北, 中国 \\ a7849800@qq.com
}

关键词：体育赛事; 武汉地方旅游业; 发展对策

中文摘要. 近年来, 体育赛事作为一个新的平台, 促进了武汉地方旅游产业的发展。本文以 体育赛事与旅游业相关理论为基础, 探讨武汉体育赛事及武汉旅游业的发展现状，分析武汉 体育赛事对地方旅游业发展的特点及影响，提出健全管理体制、优化赛事布局、整合资源、 创新设计相关产品、搭建平台等建议, 为促进武汉经济快速增长, 推动武汉旅游产业与体育 赛事联合发展提供参考。

\section{1. 引言}

近年来，随着经济的快速发展，人们的生活水平持续提升，我国旅游产业的发展出现了 新的增长点, 为了满足人们日益增长的需求, 越来越多的城市都开始通过举办大型体育赛事 促进旅游业的发展, 体育赛事不仅能给参与的群体提供视觉享受与精神愉悦, 还能衍生出更 多休闲娱乐活动。武汉市作为国家中心城市，九省通瞿，有着丰富的自然资源和浓厚的历史 底蕴, 近年来, 武汉市旅游特色与服务不断加强, 旅游业有可持续发展的优势。为加快武汉 经济快速发展, 武汉举办和承办了各类大型体育品牌赛事, 如武汉网球公开赛、亚洲羽毛球 锦标赛、武汉国际马拉松、武汉国际渡江节等，体育赛事的举办为武汉旅游产业的发展搭建 了重要平台。

国外对于体育赛事对城市旅游业发展的相关研究起步较早，一批学者对其进行了深入的 探究, 涉及到的方面有: 体育赛事的影响、赛事品牌的建立、体育赛事旅游的市场营销等。 而我国针对这方面的研究起步相对较晚, 研究较少。尽管目前武汉通过体育赛事使旅游人数 
增加、旅游产业的客源结构改善、旅游收入和就业机会增加、旅游产业政策优化, 但体育赛 事对武汉地方旅游业的发展仍然存在一些问题。因此, 分析武汉体育赛事和武汉旅游业的现 状, 从地方旅游业发展入手, 提出基于体育赛事的武汉地方旅游业发展对策, 对促进武汉地 方旅游产业的发展, 把武汉建设成旅游目的具有重要的理论和实际意义。

\section{2. 武汉体育赛事和武汉旅游业发展现状分析}

\section{1 武汉体育赛事发展现状}

近年来，武汉体育赛事发展快速，为武汉旅游业的发展注入了强大的动力，成为武汉经 济快速发展与社会进步的重要推动力。武汉发展的品牌赛事有武汉国际渡江节、武汉网球公 开赛, 武汉马拉松等, 举办这些品牌赛事对于武汉而言是机遇与挑战并存, 有利于提升武汉 的国际形象, 但是武汉体育产业发展过程中还存在很多问题, 主要有武汉市居民在体育劳务 消费方面所占比例比在体育实物消费方面所占比例多, 居民体育消费由于整个消费结构等因 素的影响, 体育消费的意愿不是很大, 另外, 武汉市民经济收入增幅不大, 愿意观看体育赛 事的比重不高, 体育产业发展相对滞后。为提高武汉城市形象, 促进武汉经济发展, 武汉不 断引进多种类型的大型体育赛事, 打造体育品牌赛事, 体育赛事规模不断扩大。

\section{2 武汉旅游业发展现状}

武汉作为国家中心城市, 地理位置较好, 九省通睢, 自然资源丰富, 历史底蕴浓厚。黄 鹤楼位居 “江南三大名楼” 之首而闻名天下。东湖是中国最大的城中湖, 归元寺内藏五百罗 汉被誉为 “佛都古刹” , 此外还有古琴台、晴川阁、楚天台等著名历史文化景点, 东湖绿道、 汉口江滩、中山大道江汉路等观光休闲景点。汉绣剧场、万达电影乐园、光谷国际网球中心 等文娱设施投入使用。2015年年末武汉旅游景区有 36 个, 其中 $5 \mathrm{~A}$ 级有 3 个, 4A 级有 5 个, $3 \mathrm{~A}$ 级有 17 个, 旅游星级以上宾馆 81 家, 全年接待了国内的旅游者达到 21032.98 万人次, 比上一 年增加了 $10.0 \%$; 接待了海外的旅游者达到 202.27 万人次, 增加了 $18.6 \%$, 实现了武汉旅游总 收入达到 2188.97 亿元, 增加了 $12.3 \%$, 其中, 国内旅游收入 2115.23 亿元, 增长 $11.8 \%$; 国际 旅游收入 12 亿美元，增长 $28.5 \%$ 。

\section{3. 体育赛事对武汉地方旅游业发展的积极影响}

近年来, 武汉体育赛事不断发展, 第六届全国城市运动会、亚洲羽毛球锦标赛, 世界体 育舞蹈锦标赛等一系列赛事的举办吸引了一大批前来观看赛事的游客, 如2014年武汉网球公 开赛的观众规模就有 7.5 万人。武汉速度赛马公开赛、“同城双星” 龙舟赛、武汉马拉松等赛 事的举办成为武汉特有的旅游资源。武汉东方马城附近有园博园和汉口里等景点, 观众在看 赛马赛事后可以到这些景区参观游玩; “同城双星” 龙舟赛于每年端午节在武汉东湖举行, 东湖风景区是武汉著名的旅游景点, 观众可以在旅游的同时观看赛事; 2016年开始的武汉马 拉松, 赛道沿途跨江越湖, 风景宜人, 路线设计逐一展现了武汉精华景点, 包括汉口江滩、 吉庆街、六渡桥、东湖绿道等, 让参加和观看比赛的人们可以感受到武汉旅游景点的风采, 增加人们在武汉旅游的兴趣。在武汉旅游信息中就有以武汉国际赛马节和武汉国际渡江节等 为主题的节庆活动和世界体育舞蹈锦标赛等赛事旅游信息。2016年武汉旅游规划也策划推出 “武网”与 “法网” 互动等旅游活动。武汉木兰山登山节暨全国登山大会至使以木兰山为核 心的木兰景区成为 $5 \mathrm{~A}$ 级风景区。在国家体育总局公布 “2016中国体育旅游精品项目入选名单” 中, 武汉马拉松和武汉网球公开赛均入选中国体育旅游精品赛事。 


\section{1 促进武汉旅游环境的改善, 完善基础设施建设}

目前，体育赛事促进武汉完善了城市基础设施建设，提升了生态环境质量，增添了旅游 吸引物。如环中国国际公路自行车赛武汉赛区部分赛段在江夏区, 首届环中赛时江夏区组织 有关部门维修赛道达 14 处, 整修了中州大道全线 2.8 公里, 拆调了减速板6处、清理了标牌广 告等1147处。另外, 还在其沿线补栽了乔木 400 多株、灌木 3600 多株、绿化草坪的面积高达 1600 平方米。这些措施不但给体育比赛带来了更好的环境, 而且改善了沿线住户出行和生活的环 境，同时也为今后以更低的成本举办这类大型体育赛事打下了良好的基础。

\section{2 提高武汉旅游业的管理水平和服务质量}

举行大型体育赛事不但可以提升政府的服务管理水平，也可以促进旅游企业进一步与国 际接轨, 从而提高了旅游企业的人才素质、管理水平和服务质量, 促使了武汉旅游产业的进 一步成熟和发展。大型体育赛事的大多数观众都是属于高收入群体, 他们一般对旅行社的服 务水平有相对较高的要求, 特别是国外的游客, 因此, 旅行社会更加重视强化企业员工的行 为规范和良好服务意识。

\section{3 提升武汉知名度, 宣传武汉旅游形象}

各界媒体长时间与高密度的宣传推广将提升武汉的知名度。体育赛事不仅带来大量人流、 物流、信息流与资金流，并提升了武汉知名度及武汉的整体形象，并且高知名度与优秀形象 有利于旅游业发展。如武汉国际赛马节、武汉网球公开赛和武汉马拉松比赛等赛事的举办都 有助于提高武汉的知名度, 提升武汉的旅游形象。

\section{4 带动武汉旅游经济快速发展}

在举行国际性体育赛事期间，入境的国外旅客的消费水平较平常高，集中消费高，外汇 收入增加量多。扩大就业机会。2014年首届武汉网球公开赛为武汉创造了11.3亿元人民币的 经济产出和 3700 个新增就业岗位, 其中就覆盖到了旅游产业。增加了游人数, 武汉举办多项 体育赛事, 会带来参赛人员, 赛事相关人员, 观赛人员等进入武汉, 一定程度上可以增加来 武汉旅游的人数, 从而促进武汉旅游经济发展。此外, 由于体育赛事受季节影响较小, 武汉 从4月到 11 月基本上都有赛事进行, 错峰举办赛事, 能够调整旅游淡旺季的时间, 在武汉旅 游的淡季时可举办体育赛事, 增添体育赛事旅游产品, 吸引不同类型的旅客, 使旅游设施的 利用率能够增大。大型体育赛事的举办会吸引很多国内外知名企业的投资, 从而促进了旅游 经济的发展。

\section{4. 基于体育赛事的武汉地方旅游业发展对策}

\section{1 优化赛事布局, 增强可持续发展动力}

以重点赛事为突破口，充分施展政府、社会与市场的力量将武汉大型体育赛事打造为国 际知名品牌。武汉市应积极承办国内外大型体育赛事, 如武汉马拉松比赛, “同城双星” 龙 舟赛, 武汉速度赛马公开赛等, 积极打造集观赏和休闲参与于一体的休闲体育项目; 塑造具 有估计影响力的品牌赛事, 提升武汉体育赛事知名度, 扩大武汉影响力, 吸引更多的人到武 汉来旅游, 增加旅游收入, 促进武汉旅游产业发展, 如武汉国际赛马节, 武汉国际横渡长江 节, 武汉木兰山登山节暨全国登山大会等大型赛事, 利用体育赛事本身及场地等特点, 吸引 来观看体育赛事人员在武汉旅游; 打造高端赛事, 吸引高端人群, 如武汉网球公开赛, 环中 国国际自行车公路赛, 中国汽车漂移锦标赛等, 科学规划利用体育赛事场馆, 增强武汉网球 中心, 沌口体育中心等体育场馆的旅游功能, 增强赛后体育场馆可持续发展, 促进高端人群 赛事旅游的发展; 实施适当的价格政策, 对赛事旅游者必须购买的产品如赛事门票等规定价 格上限, 对于不是必须产品的价格可以由市场进行调节, 适当保持有一些中低档价格的产品, 
为低收入的体育赛事爱好者提供观赛并进行旅游的机会, 树立武汉良好的形象, 促进武汉旅 游业的发展。

\section{2 统筹规划, 整合资源}

结合武汉现在和未来的城市规划、武汉体育和旅游规划和武汉实际情况, 制定相应的体 育赛事与武汉旅游业互动发展的规划, 注重规划的连续性, 可行型以及体现武汉大型体育赛 事与武汉的特点, 满足游客和赛事观众的需求; 充分利用政府和市场力量整合资源, 一起打 造体育赛事旅游精品路线, 组合多条观赏、参赛路线, 体育休闲旅游路线以满足不同需求的 游客。如武汉国际赛马节, 可将东方马城和附近的高尔夫球场联合起来, 两个地方都是既能 满足人们赛事旅游的需求又可以体现出人的身份和地位; 将武汉体育赛事与武汉旅游景点的 营销相联合, 实行一些相关的优惠政策, 如体育赛事与旅游景点门票配套出售享受折扣优惠, 或报相关赛事旅游的旅游团享受相关优惠, 或持有某场武汉体育赛事的门票在有效期内到武 汉相关旅游景点可享受门票折扣优惠, 或赠送相关旅游景点纪念品, 或可以免费参与旅游景 点的一项娱乐设施, 或可以享受体验亲自项目的折扣优惠等。

\section{3 创新并完善配套旅游产品设计，延长武汉体育赛事旅游的产业链}

与武汉体育赛事及武汉旅游业发展的相关主体积极配合, 不断设计赛事旅游精品专业化 路线, 设计有关的赛事旅游活动及产品。门票销售可以吸引球迷前来观赛, 带动周围旅游产 业的发展, 赛事运营能够吸引运动员和户外运动爱好者加入, 从而转变为旅游经济。如可借 助武汉龙舟赛设计水上休闲体育旅游产品, 建立以水为主题的主题公园, 设计与龙舟和水有 关的旅游产品吸引游客, 推动体育赛事武汉旅游业的发展; 设计有武汉体育赛事旅游特色的 纪念品, 一般纪念品都具有收藏价值, 有利于宣传和推广武汉旅游特色和体育赛事文化。可 以利用赛事特点及武汉旅游特色设计一些与武汉赛事旅游相关的吉祥物, 衣帽, 手链, 钥匙 扣, 纪念型旅游卡, 海报等, 如武汉马拉松, 可以在沿线旅游景点都设置一些纪念品专卖点, 在纪念品的设计中加入武汉马拉松路线中有武汉特色的旅游景点如黄鹤楼, 东湖梅园等, 还 有民众乐园, 六渡桥, 吉庆街等老汉口风情。吸引游客, 增加旅游收入; 研发各种形式的体 育赛事旅游产品。利用体育赛事本身特点及武汉举办该赛事场馆和周边区域的特点, 开发特 色的旅游项目, 可以增加亲自项目, 美食区等。如在东方马城举行的武汉速度赛马公开赛, 可以在门票销售的同时搭配休闲骑乘的销售或开发一些垂钓, 亲子项目等, 吸引赛事观众, 增加旅游收入。

\section{4 搭建赛事旅游平台，加强对武汉体育赛事的宣传}

打造体育产业发展新平台。启动国家体育产业联系点工作。大力发展体育休闲运动。全 面提升大型体育赛事的国际影响力, 着重培养体育消费, 加快开拓赛事旅游市场, 策划体育 赛事旅游相关活动; 通过招赞助商, 获得相应物质的支持, 所招的赞助越多, 获得的资金越 多, 有利于吸引更多的参赛者, 也有利于增强游客对体育赛事的参与度。利用广告进行宣传, 在车站站牌, 体育馆门口, 商场门口等人流量大的地方张贴体育赛事的海报, 在电视、网络 上等播放宣传广告, 加强与各界媒体之间的合作，体育赛事与武汉旅游推广相结合，通过媒 体充分展现体育赛事及举办城市的鬼米力, 吸引人们前来观看体育赛事并进行旅游, 促进武汉 体育赛事对地方旅游业的发展; 搭建网络宣传促销平台, 开发武汉体育赛事旅游手机APP, 在手机APP中可设计有免费代理赛事报名和搭配名额的赛事旅游套餐, 手机APP中也应销售 观赛产品, 介绍并销售围绕武汉体育赛事IP设计的体育旅游产品、体育景观游、体育培训游、 运动体验游等有关旅游产品, 手机APP中还应有关于武汉赛事旅游的攻略, 时间安排, 住宿 酒店介绍, 武汉旅游景点介绍, 武汉特色美食信息, 用户进行赛事旅游后的意见反馈等功能, 通过把武汉体育赛事与相关旅游信息进行结合宣传, 使游客能够更加全面的了解武汉, 给人 们参加赛事旅游的出行带来方面, 促进旅游业的发展。 


\section{5 制定管理对策, 加强管理}

建立健全武汉体育赛事与地方旅游业发展的相关管理体制，使其相关配套产品，政策扶 持, 产品设计等协调发展; 加大武汉政府的支持与监督力度。武汉政府需要加强对武汉体育 赛事的投融资力度，完善有关税费的一些优惠政策，增强执法队伍的建设，加大体育赛事赛 前、赛中、赛后的监管力度, 努力建立公平公正的赛事运营体系, 逐渐建立健全市场监管机 制, 如政府应该对体育赛事期间出现的物价上涨运用相关的政策手段进行宏观调控, 对于体 育赛事中可能出现的一些安全隐患，政府和有关部门要提前做好应对安全隐患的紧急方案的 制定; 体育部门和旅游部门要转变观念, 深化合作, 促进体育体制改革, 促使旅游业的优化 升级, 将体育产业和旅游业进行联合, 加强宣传力度, 使武汉体育赛事旅游被人们熟知, 增 强武汉体育赛事对旅游产业的影响力; 加速人才培养, 培养及引进一批既懂体育赛事又懂市 场规律的复合型高水平人才, 加强对相关管理人员的培训, 增强校企合作实现企业与学校双 赢, 满足武汉体育赛事促进地方旅游业发展的用人之需; 加强配套基础设施建设并且做好环 境保护工作。在武汉体育赛事举办的期间, 武汉应该加大宣传保护赛事环境, 制定相关体育 赛事环境保护的措施, 综合治理武汉城市环境, 在体育赛事的设施, 材料, 能源建设等方面, 运用先进的科学技术使赛事相关设施的建设达到绿色环保, 为武汉体育赛事促进地方旅游产 业发展营造绿色的生态环境。

\section{5. 结束语}

在武汉市承办和举办越来越多的体育品牌赛事的背景下，体育赛事对武汉地方旅游业发 展的影响越来越大。武汉举办体育赛事可以增加武汉旅游人数, 完善基础设施, 提高旅游业 管理水平和服务质量, 提升武汉知名度, 宣传武汉城市形象。体育赛事给武汉市带来的机遇 与挑战并存，发展过程中存在着武汉赛事和旅游部门的管理观念和合作意识不强、基础设施 建设不够、缺少政府支持和针对性的法律法规支持、保障和激励等长效机制不健全，可持续 发展动力不够等问题。因此, 需要把握机遇, 加强管理优化体育赛事布局, 统筹规划, 整合 资源, 不断创新完善配套旅游产品的设计, 延长体育赛事旅游的产业量, 制定管理对策加强 管理，增强可持续发展动力，使体育赛事可以更好的促进武汉地方旅游业的发展。

\section{致谢}

本文为湖北省人文社会科学研究项目《湖北省赛马产业价值创造模式与发展对策研究》 （18G057）的阶段性成果之一。

\section{References}

[1] J. X. Liang, and Y. T. Cai, Design and application of network management system for sports events, Applied Mechanics and Materials, vol. 263-266, pp. 3357-3360, 2013.

[2] X. Sun, A. May, and Q. F. Wang, Investigation of the role of mobile personalisation at large sports events, International Journal of Mobile Human Computer Interaction, vol. 9, pp. 1-15, 2017.

[3] X. R. Zhang, and J. H. Sun, Discussion on new media communication strategy of sports events based on large data technology, Cluster Computing, vol. 1, pp. 1-9, 2018.

[4] X. C. Zhang, On F1 Match promoting sustainable development of Shanghai tourism industry, Journal of Shandong Institute of Physical Education and Sports, vol. 26, pp. 31-35, 2010.

[5] Z. D, Lin, Analysis on social and economic influence of large-scale sports events, Metallurgical and Mining Industry, vol. 7, pp. 49-54, 2015. 